International Jaurnal of Madern Anthropolagy

Int. J. Mod. Anthrop. 2019. Vol. 2, Issue 12, pp: 97- 113

DOI: http://dx.doi.org/10.4314/ijma.v2i12.4

\title{
Genetic affinity of Muslim population in South India based on HLA-DQB1 and relationship with other Indian Populations
}

\author{
Koohyar Mohsenpour ${ }^{1 *}$ and Adimoolam Chandrasekar ${ }^{2}$ \\ ${ }^{1}$ Department of Studies in Anthropology, University of Mysore, Manasa Gangothri, Mysore-570006, Karnataka, India. \\ ${ }^{2}$ Anthropological Survey of India, Southern Regional Center, Government of India, Mysore-570026, India. \\ Correspondant author: Koohyar Mohsenpour. E. mail: kohyarmohsenpour@gmail.com
}

(Received 15 January 2019; Accepted 25 February 2019; Published 2 April 2019)

\begin{abstract}
The present study made an attempt to observe genetic affinity of the Muslim population in South India with other neighbor populations. In this regard, DQB1 loci of HLA class II gene as a common genetic marker in phylogenetic assessment has been examined in 45 unrelated healthy individuals using sequence-based typing. The result of this study indicates a close genetic similarity among Indian sub-populations, in spite of segregation with other Muslim populations in North India. Although results of present study indicates genetic relationship of selected populations, all HLA loci or at least all loci of each classes to be assessed in order to attain highly probability of estimates.
\end{abstract}

Keywords: South Indian Muslims, Anthropology, HLA 


\section{Introduction}

Human leukocyte antigen (HLA) genes are highly polymorphic genes in human which are considered widely as a useful autosomal genetic marker beside the traditional sex chromosomes markers like as mtDNA and Y chromosome for population relationship and phylogenetics. HLA genes are regarded as a useful marker for immunologist in the clinical context and anthropological purpose to investigate the genetic structure of human population and determine affinities between neighboring populations (Sanchez-Mazas 2001; Spínola et al. 2011). HLA genes widely analyzed as useful markers to identify genetic relationship among populations by molecular anthropologist. Genetic relationship and similarity of HLA class II gene between Muslim population in South India in Karnataka state and neighbor populations has been aimed for the present study.

\section{Material and Methods}

\section{Population Background \& Cultural Characteristics}

Population under the study inhabited in Srirangapatna (also spelled Shrirangapattana) located near the city of Mysore in Karnataka state at the Southern region of India. Srirangapatna is an important historical area with considerable religious, spiritual, natural, and cultural background. After Hinduism, Islam is second largest religion in India. According to 2011 census, 172 million of country's population constitutes from Muslims (14.2\%). Accordingly, India has the third largest population of Muslims in the world, after Indonesia and Pakistan. The arrival of Muslims in South Asia traced back to Arab traders entry to Malabar (geographic area in Southwest India, covering the Kerala), during the early $7^{\text {th }}$ century, even very earlier than Islam inter to India. Although entry of the Arab Muslim into India around thousand years ago take placed from North-western India and expand to the south and east. The pattern of Muslims entering to India can be considered in three successive waves, the Arabs in $8^{\text {th }}$ century, multiple Turkish people arrived around 1000 C.E., and the Mughal dynasty that entered in 1526. This cycle continued till intrusion of the British who would present India with a new cultural challenge. Share of Muslim 
populations in Karnataka increased from 9.87 in 1961 to 12.92 percent (2011) in the population of Karnataka. The share of Muslims in Karnataka has been rising consistently between 1961 and 2011, except a slight decline in the first decade following Independence. Current distribution of Muslims across the State has been shown in Map.1.

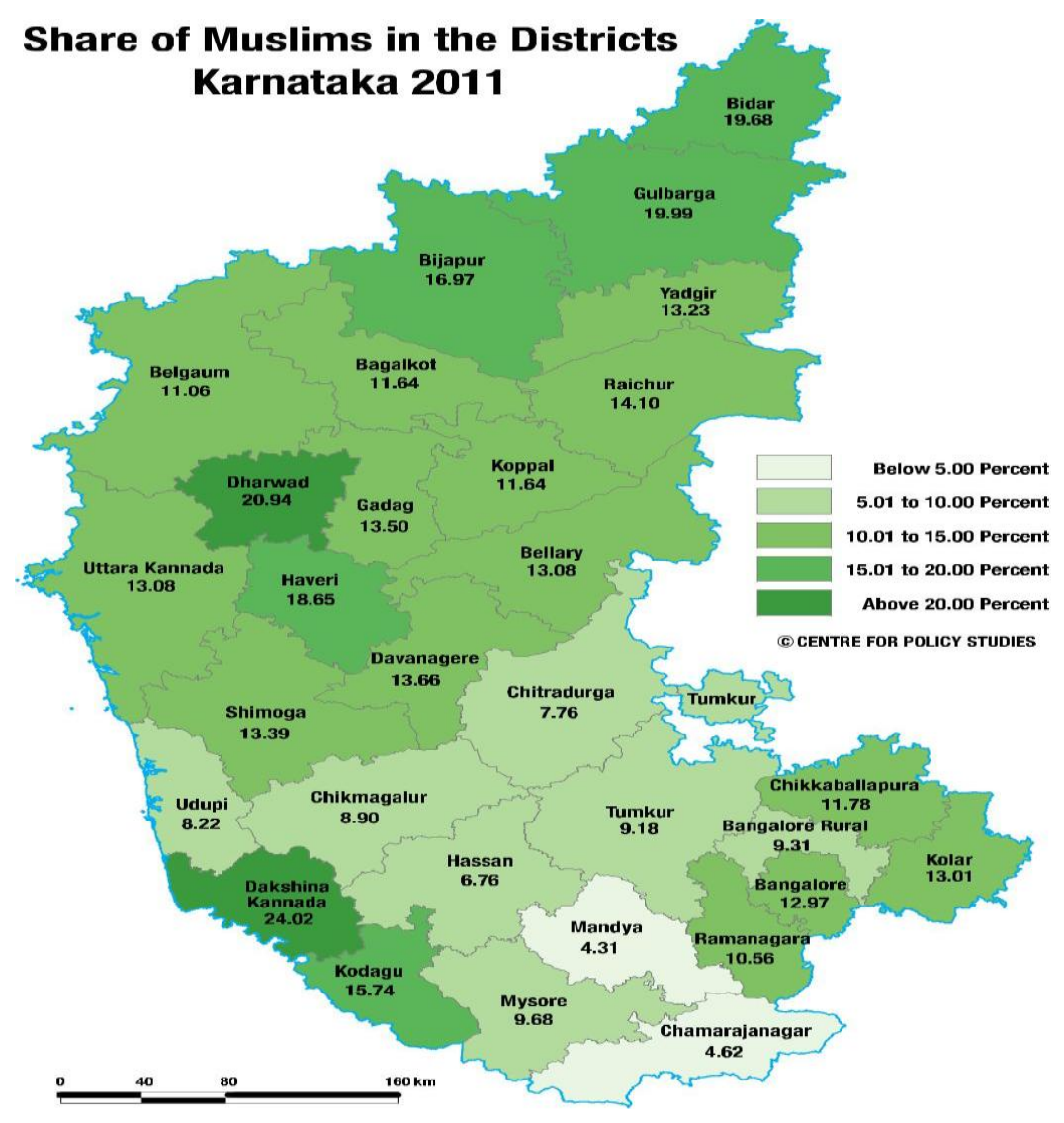

Map.1 Muslims populations distribution in Karnataka State (www.cpsindia.org).

Shrirangapattana Muslims are an endogamous population with Interbreeding and intergroup marriage; cousin or cross-cousin marriages are prevalent among Muslims of Shrirangapattana to keep wealth in their family and to maintain the purity of lineage. For this reasons, population might be carrying specified gene pool that culturally influenced than 
neighbor populations. Urdu is the main spoken language of Muslims in Karnataka with Dakhni accent, however most Muslims in Karnataka also speak Kannada, Telugu and Sindhi.

\section{Geography}

Srirangapatna town is $12 \mathrm{~km}^{2}$ where is located at $12.41^{\circ} \mathrm{N} 76.7^{\circ} \mathrm{E}$ on the southeast of Mandya district with an average elevation of 679 meters. The area is bounded by Mysore district on its south and southwest, Mandya and Maddur town on its east and Krishnarajanagar on its west. It is situated near the River Cauvery to form an oval shaped island (Map.2).

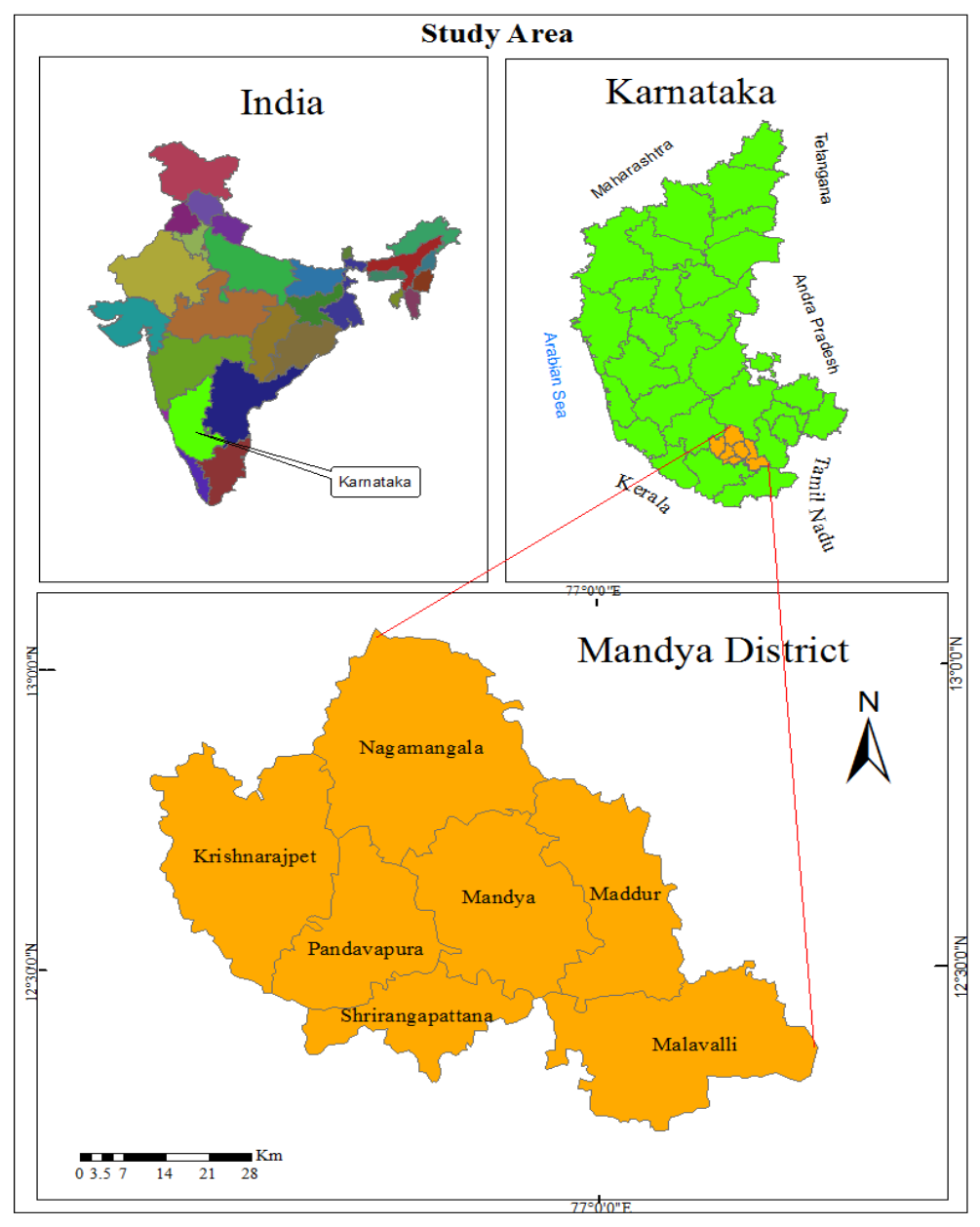

Map. 2 Field area, Srirangapatna (www.cpsindia.org). 


\section{Samples}

According to census of $2011,49 \%$ of the population is male and $51 \%$ is female. Religion proportion assigned by $74 \%$ Hindus and $24 \%$ Muslims of the whole population, rest of the population are Christians and Sikhs. Total population size of Muslims is 3102 persons, 1463 males and 1639 females. A total of 45 blood samples from unrelated healthy individuals were taken randomly after obtaining informed consent based on institute ethical committee approval. The origin of all persons was belonging to Muslim family and has been inhabited in this area for at least three generations.

\section{DNA Extraction and Genotyping}

Genomic DNA was isolated using QIAamp DNA Mini Kit (Qiagen, Hilden, Germany) and has been checked for the quality by $1 \%$ agarose gel electrophoresis. Genomic DNA was amplified at the exon-2 of HLA-DQB1 with the PCR condition of $40 \mathrm{ml}$ reaction mixture subjected to 35 cycles of $95{ }^{\circ} \mathrm{C}$ for $3 \mathrm{~min}, 95^{\circ} \mathrm{C}$ for $30 \mathrm{~s}, 62^{\circ} \mathrm{C}$ for $30 \mathrm{~s}$, and $72{ }^{\circ} \mathrm{C}$ for $45 \mathrm{~s}$, and a final extension at $72{ }^{\circ} \mathrm{C}$ for $10 \mathrm{~min}$. The nucleotide sequences of the PCR products were identified by direct sequencing with both the forward and reverse directions using 3730 DNA analyzer (Big Dye, Applied Biosystems).

\section{Statistical Analysis}

All analyses in present study based on allele frequency variation in HLA-DQB1 gene of eleven ethnic groups from India and twenty two populations from all over the different geographical regions that were obtained from ( http://allelefrequencies.net/ ) database (González-Galarza et al. 2014). All nucleotide changes were identified by using SeqScape software V2.5 (Applied Biosystems) to detect synonyms and non-synonymous substitution in comparison with the most homologous allele, and allele groups were detected according to IPD-IMGT/HLA Database (https://www.ebi.ac.uk/ipd/imgt/hla/) and nomenclature information (Robinson et al. 2014; Marsh et al. 2010). Allele frequencies were obtained via direct counting. DQB1 locus showed a huge variation and many alleles contained very low frequencies. In order to perform a comparison of allele frequencies among various populations, it was necessary in some cases, to consider allele groups in the analysis, losing in part the high power of resolution of this study

(Piancatelli et al. 2004). To overcome this problem, all the alleles were classified in 5 corresponding two-digit lower resolution allele groups of HLA-DQB1 to use in Arlequin vr3.5 
(Excoffier and Lischer 2010) and SPSS, v 17.0 (SPSS, Inc.). Analysis of molecular variance (AMOVA) to estimate the distribution of genetic diversity between and among populations was performed using Arlequin. Neighbour joining trees constructed according to $F_{\text {st }}$ distance (Latter 1972) that were computed by Poptree2 (Takezaki et al. 2009) software. Principal component analysis is used for representation of genetic differentiation via multidimensional scaling (MDS) plot (Borg and Groenen 2003) in SPSS. It should be noted that the sample size of present study and some of those in the literature are probably small when compared to the level of variations at studied loci and it is a frequently encountered problem when studying small populations and might impress lower accuracy of estimates and decrease the power of some statistical tests, however it should not substantially affect the robustness of our inferences (Spínola et al. 2011).

\section{Results and discussions}

All the literature data and their allele frequency with two-digit lower resolution have been shown in Table $1 \& 2$. It is to be noted that allele group of $* 03$ is highly frequent among target population followed by DQB $1 * 06,-* 05$ and $-* 02$ alleles with $0.2440,0.1780$ and 0.1330 values respectively, and subsequently absence of allele group *04 in present study and is very rare among other Indian populations (Agrawal et al. 2008; Kohaar et al. 2009; Seshasubramanian et al. 2018) with lowest frequency as well (Table1). Rarity of DQB1*04 allele is visible in other South and West Asian populations (Malavige et al. 2007; Mohyuddin et al. 2002; Farjadian et al. 2004) and also in some Southeast Asian (Hoa et al. 2008; Sanchez-Mazas 2006; Zhao et al. 1993) countries than other world populations. One interpretation for discrepancy in allele combinations of HLA genes between different populations is the complementary and compensatory abilities of allelic products encoded by the haplotype to bind peptide epitopes from different pathogens, another being past population differentiations or recent admixture of populations (Sanchez-Mazas et al. 2011).

Although, there are some differences among Indian subpopulations, the results of molecular variance analysis (AMOVA) strongly confirmed that genetic diversity among Indian ethnic groups was mainly confined to intra-subpopulation variations and revealed that more than 99\% of the variation components were contributed by the within population level and differentiation among populations was extremely low, in addition $\mathrm{F}_{\mathrm{st}}$ was 0.0063 which indicates little subdivision among the Indian subpopulation, and respectively more than $93 \%$ with 0.066 
$\mathrm{F}_{\mathrm{st}}$ for other world populations as well (Table 3 and 4). Genetic relationship among population of present study with both Indian ethnic groups and other countries based on $\mathrm{F}_{\text {st }}$ genetic distances has been illustrated in Figure 1 and 2 via Neighbor-joining tree. The population under the study has been located in the same cluster in adjacent to New Delhi (ND) population (Kohaar et al. 2009) North Gujarat (NG) population $(U P D)^{1}$ and a little far from two Muslim populations of India i.e. Northeast Shia (IS) and Sunni (ISU) populations (Agrawal et al. 2008) that it has depicted in Figure 1, and accordingly, considerable separation in MDS plot results represented no evidence on strong genetic affinity between Muslim groups in Northeast (Agrawal et al. 2008) area and people of object (Fig. 3). As shown in Figure 2, the Muslim population in present study is close to Eastern Asian (Sanchez-Mazas 2006; Zhao et al. 1993) and quite separated from Western Asia. The genetic relationship of target population with different world populations, reflects proximity to Greece (Kokaraki et al. 2009), Singapore (Sanchez-Mazas 2007) and Thailand (Chandanayingyong 2002) populations followed by China (Zhao et al. 1993) and Mongolia (Machulla et al. 2003) and well separated from Northeast of Asia such as Russia (Krylov et al. 1995) and South American countries (Cerna et al. 1993) which is summarizes by MDS plot (Fig. 4) and has been verified by Neighbor-joining tree which has depicted genetic relationship among present study population and other ethnic groups (Fig. 2). To emphasis on association between Indian and non-Indian Muslim populations, genetic distances were calculated between Muslim populations from Iran (Farjadian et al. 2004), Pakistan (Mohyuddin et al. 2002), Jordan (Sánchez-Velasco et al. 2001) and Saudi (UPD) with 0.105, 0.115, 0.039 and 0.054 distance values respectively, from Muslim neighbor countries; and also with Northeastern Indian Muslims (Agrawal et al. 2008), non-Muslim New Delhi population (Kohaar et al. 2009) and North Gujarat (UPD) populations with distance values 0.036, 0.040 (Northeast Indian Muslims), 0.015 and 0.017 respectively (Table 5). Neighbor-joining tree based on Nei's genetic distances demonstrated the distance results (Fig. 5). The results reflect more affinity of our target population to Indian populations especially non-Muslim Indians (with quite low distances), than Muslims in India and other countries that could be estimated their possible admixture with other Indian populations that occurred at different time intervals. These results strengthen the finding of several similar reports according to classical genetic marker such as mitochondrial DNA (Eaaswarkhanth et al. 2010; Khan et al. 2004) that resulted formerly.

\footnotetext{
${ }^{1}$ Data defined by “unpublished data (UPD)" in this study, has been collected from http://www.allelefrequencies.net
} 
Table 1 Low-resolution HLA-DQB1 allele frequencies in Indian populations

\begin{tabular}{|c|c|c|c|c|c|}
\hline \multirow{2}{*}{$\begin{array}{c}\text { Populations } \\
\text { With sample size (n) \& Reference }\end{array}$} & \multicolumn{5}{|c|}{ Alleles with frequency } \\
\hline & DQB1*02 & DQB1*03 & DQB1*04 & DQB1*05 & DQB1*06 \\
\hline $\mathrm{NG}^{*}(\mathrm{n}=338)(U P D)$ & 0.2273 & 0.3788 & 0.0152 & 0.1364 & 0.2423 \\
\hline ND $(\mathrm{n}=102)($ Kohaar et al., 2009) & 0.1860 & 0.3630 & 0.0200 & 0.1810 & 0.2500 \\
\hline MP $(\mathrm{n}=45)($ present study) & 0.1330 & 0.4440 & 0.0000 & 0.1780 & 0.2440 \\
\hline IB $(\mathrm{n}=59)$ (Begovich et al., 2001) & 0.1950 & 0.2160 & 0.0170 & 0.2130 & 0.3590 \\
\hline $\begin{array}{l}\text { IA }(\mathrm{n}=186) \text { (Seshasubramanian et al., } \\
2018)\end{array}$ & 0.1344 & 0.3119 & 0.0376 & 0.1881 & 0.3280 \\
\hline $\begin{array}{l}\text { IL }(\mathrm{n}=123) \text { (Gjertson and Terasaki, } \\
\text { 1998) }\end{array}$ & 0.2330 & 0.2710 & 0.0080 & 0.2210 & 0.2670 \\
\hline IK $(\mathrm{n}=190)$ (Agrawal et al., 2008) & 0.2390 & 0.2840 & 0.0210 & 0.1860 & 0.2880 \\
\hline IR $(n=196)$ & 0.2650 & 0.2380 & 0.0080 & 0.2250 & 0.2640 \\
\hline IS $(n=190)$ & 0.2130 & 0.3110 & 0.0450 & 0.2290 & 0.2020 \\
\hline ISU (n=188) & 0.1970 & 0.2700 & 0.0370 & 0.2890 & 0.2070 \\
\hline IU (n=202) & 0.2150 & 0.2700 & 0.0190 & 0.2030 & 0.2930 \\
\hline $\mathrm{NR}(\mathrm{n}=98)$ & 0.1630 & 0.2690 & 0.0200 & 0.3320 & 0.2160 \\
\hline
\end{tabular}

*NG: North Gujarat, ND: New Delhi pop 2, MP: Present study, IB: India Bombay, IA: Andhra Pradesh Telugu, IL: India Lucknow, IK: Northeast Kayastha, IR: Northeast Rastogi, IS: Northeast Shia \& ISU: Northeast Sunni, IU: Uttar Pradesh. NR: North Rajbanshi.

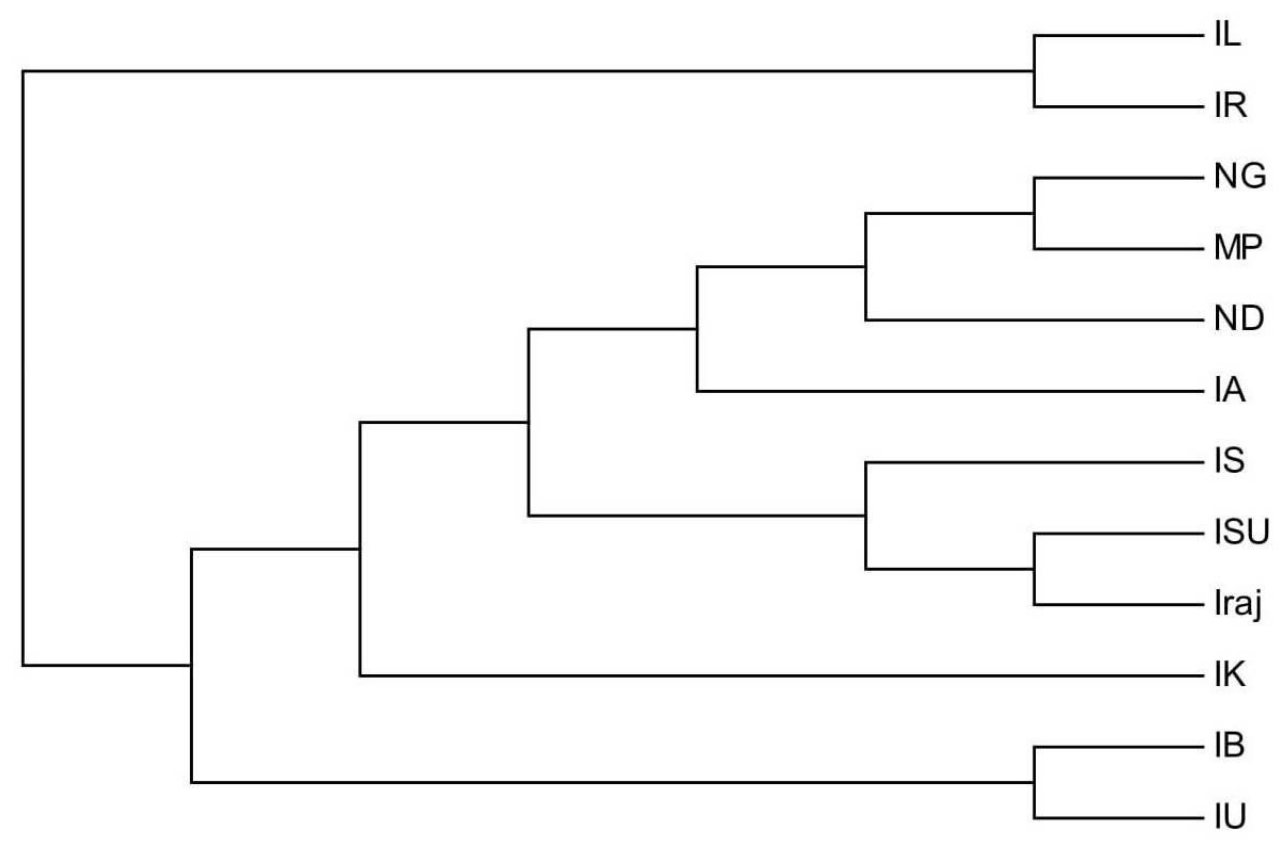

Fig. 1 Neighbor-joining tree showing the genetic relationship among population of present study and other Indian sub- populations. 
Table 2 Low-resolution HLA-DQB1 allele frequencies in 35 different world populations

\begin{tabular}{|c|c|c|c|c|c|}
\hline \multirow{2}{*}{$\begin{array}{c}\text { Populations } \\
\text { With sample size (n) \& Reference }\end{array}$} & \multicolumn{5}{|c|}{ Alleles with frequency } \\
\hline & $\mathrm{DQB} 1 * 02$ & $\mathrm{DQB} 1 * 03$ & $\mathrm{DQB} 1 * 04$ & $\mathrm{DQB} 1 * 05$ & $\mathrm{DQB} 1 * 06$ \\
\hline $\operatorname{Vietnam}^{*}(\mathrm{n}=170)$ (Hoa et al. 2008) & 0.0910 & 0.5490 & 0.0410 & 0.2180 & 0.1010 \\
\hline Srilanka $(\mathrm{n}=101)$ (Malavige et al. 2007) & 0.1920 & 0.1920 & 0.0100 & 0.2980 & 0.3080 \\
\hline Japan $(\mathrm{n}=371)$ (Saito et al. 2000) & 0.0030 & 0.3570 & 0.1540 & 0.1370 & 0.3490 \\
\hline Korea $(\mathrm{n}=324)(U P D)$ & 0.0850 & 0.3370 & 0.1160 & 0.1710 & 0.2910 \\
\hline MongoliaK (n=200) (Machulla et al. 2003) & 0.1750 & 0.4300 & 0.0950 & 0.1200 & 0.1800 \\
\hline MP $(\mathrm{n}=45)($ present study) & 0.1330 & 0.4440 & 0.0000 & 0.1780 & 0.2440 \\
\hline RussiaSE $(\mathrm{n}=70)$ (Krylov et al. 1995) & 0.0590 & 0.7430 & 0.1000 & 0.0800 & 0.0180 \\
\hline BrazilPX $(\mathrm{n}=74)$ (Cerna et al. 1993) & 0.0000 & 0.7350 & 0.2650 & 0.0000 & 0.0000 \\
\hline $\operatorname{ArgentinaCH}(\mathrm{n}=54)(U P D)$ & 0.0180 & 0.7590 & 0.1500 & 0.0460 & 0.0270 \\
\hline SingapoRM $(\mathrm{n}=132)$ (Sanchez-Mazas 2007) & 0.1090 & 0.4280 & 0.0180 & 0.2630 & 0.1820 \\
\hline ItalyR $(\mathrm{n}=100)$ (Testi and Mariani 1998) & 0.1950 & 0.4250 & 0.0400 & 0.1750 & 0.1650 \\
\hline Greece $5(\mathrm{n}=500)($ Kokaraki et al. 2009) & 0.1270 & 0.4170 & 0.0040 & 0.2770 & 0.1750 \\
\hline IsraelLj (n=119) (Amar et al. 1999) & 0.3330 & 0.4370 & 0.0260 & 0.0660 & 0.1380 \\
\hline $\operatorname{IranYZ}(\mathrm{n}=65)(U P D)$ & 0.2390 & 0.3690 & 0.0620 & 0.1150 & 0.2150 \\
\hline Thailand $(\mathrm{n}=142)$ (Chandanayingyong 2002) & 0.1270 & 0.3950 & 0.0460 & 0.2990 & 0.1330 \\
\hline $\operatorname{IraqE}(\mathrm{n}=79)(U P D)$ & 0.2152 & 0.4810 & 0.0190 & 0.1329 & 0.1519 \\
\hline Malay $(\mathrm{n}=62)($ Sanchez-Mazas 2007) & 0.0580 & 0.3840 & 0.0120 & 0.3740 & 0.1720 \\
\hline Saudi $(\mathrm{n}=499)(U P D)$ & 0.3615 & 0.2508 & 0.0188 & 0.1233 & 0.2456 \\
\hline PakisB $(\mathrm{n}=66)$ (Mohyuddin et al. 2002) & 0.3970 & 0.1120 & 0.0090 & 0.3400 & 0.1420 \\
\hline IranB $(\mathrm{n}=100)$ (Farjadian et al. 2004) & 0.3200 & 0.1450 & 0.0300 & 0.3800 & 0.1250 \\
\hline Jordan ( $\mathrm{n}=146)$ (Sánchez-Velasco et al. 2001) & 0.3600 & 0.2810 & 0.0000 & 0.1410 & 0.2180 \\
\hline Leb $(\mathrm{n}=191)$ (Samaha et al. 2003) & 0.1950 & 0.5070 & 0.0260 & 0.1990 & 0.0730 \\
\hline China3 $(\mathrm{n}=58)$ (Zhao et al. 1993) & 0.0950 & 0.4990 & 0.0690 & 0.0950 & 0.2420 \\
\hline
\end{tabular}

*Vietnam: Vietnam Hanoi Kinh pop 2, Srilanka: Sri Lanka Colombo Sinhalese, Japan: Japan Central, Korea: South Korea pop 1, Mongolia_K: Mongolia Khalkha, MP: Present study, RussiaSE: Russia Siberia Eskimo, BrazilPX: Brazil Central Plateau Xavante, ArgentinaCH: Argentina Chiriguano, SingaporeRM: Singapore Riau Malay, ItalyR: Italy Rome, Greece5: Greece pop 5, IsraelLj: Israel Libyan Jews, IranYZ: Iran Yazd Zoroastrian, IraqE: Iraq Erbil, Malay: Malaysia pop 2, Saudi: Saudi Arabia pop 4, PakisB: Pakistan Baloch, IranB: Iran Baloch, Jordan: Jordan Amman, Leb: Lebanon pop 2, China3: China Shanghai pop3.

Table 3. Summary of AMOVA analysis based on DQB1 allele frequency of Indian populations

\begin{tabular}{lllll}
\hline Source of variation & df & SS & VC & PV \\
\hline Among populations & 11 & 8.277 & 0.00241 & 0.64 \\
Within populations & 1907 & 715.599 & 0.37525 & 99.36 \\
Total & 1918 & 723.875 & 0.37766 & \\
Fixation index & & FST: 0.00638 & & \\
\hline
\end{tabular}

df: degree of freedom, SS: sum of squares, VC: variance components, PV: percentage of variation

Table 4 Summary of AMOVA analysis based on DQB1 allele frequency of different world populations

\begin{tabular}{lllll}
\hline Source of variation & df & SS & VC & PV \\
\hline Among populations & 22 & 92.154 & 0.02485 & 6.65 \\
Within populations & 3646 & 1271.161 & 0.34865 & 93.35 \\
Total & 3668 & 1363.315 & 0.37350 & \\
Fixation index & & FST: 0.06654 & & \\
\hline
\end{tabular}


Table 5 Genetic distances of nine pairs of Indian and Indian Muslims and four neighbor country Muslim populations.

\begin{tabular}{|c|c|c|c|c|c|c|c|c|}
\hline & 2 & 3 & 4 & 5 & 6 & 7 & 8 & 9 \\
\hline 1. Saudi & 0.049 & 0.054 & 0.011 & 0.054 & 0.015 & 0.022 & 0.023 & 0.032 \\
\hline 2. PakisB & $* * * *$ & 0.007 & 0.050 & 0.115 & 0.081 & 0.077 & 0.054 & 0.043 \\
\hline 3. $\operatorname{Iran} B$ & & $* * * *$ & 0.062 & 0.105 & 0.073 & 0.063 & 0.036 & 0.025 \\
\hline 4. Jordan & & & $* * * *$ & 0.039 & 0.019 & 0.029 & 0.038 & 0.044 \\
\hline 5. Mp* & & & & $* * * *$ & 0.017 & 0.015 & 0.036 & 0.040 \\
\hline 6. NG & & & & & $* * * *$ & 0.003 & 0.013 & 0.022 \\
\hline 7. ND & & & & & & $* * * *$ & 0.007 & 0.012 \\
\hline 8. IS & & & & & & & $* * * *$ & 0.003 \\
\hline 9. ISU & & & & & & & & $* * * *$ \\
\hline
\end{tabular}

*present study population

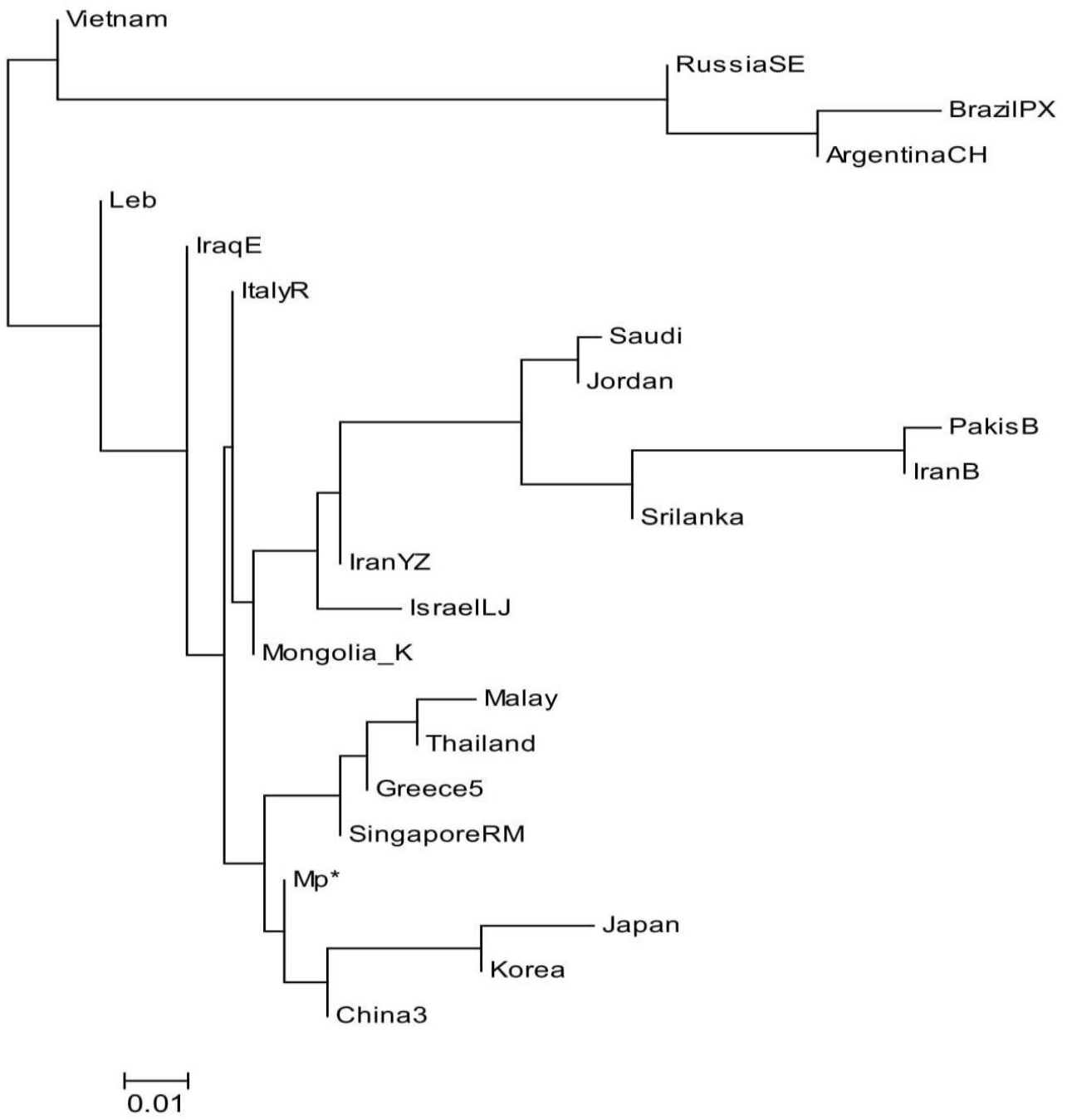

Fig. 2 Neighbor-joining tree showing the genetic relationship among population under study and other world populations. 


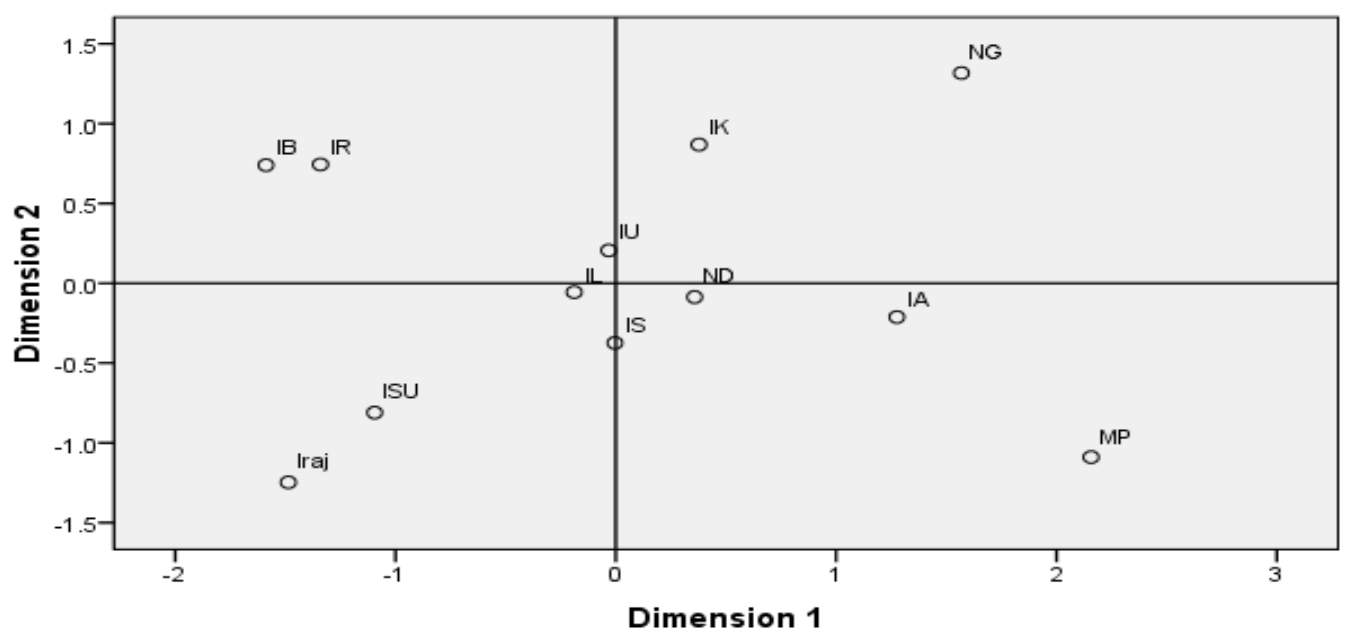

Fig. 3 MDS plot to representation of genetic differences of Indian populations

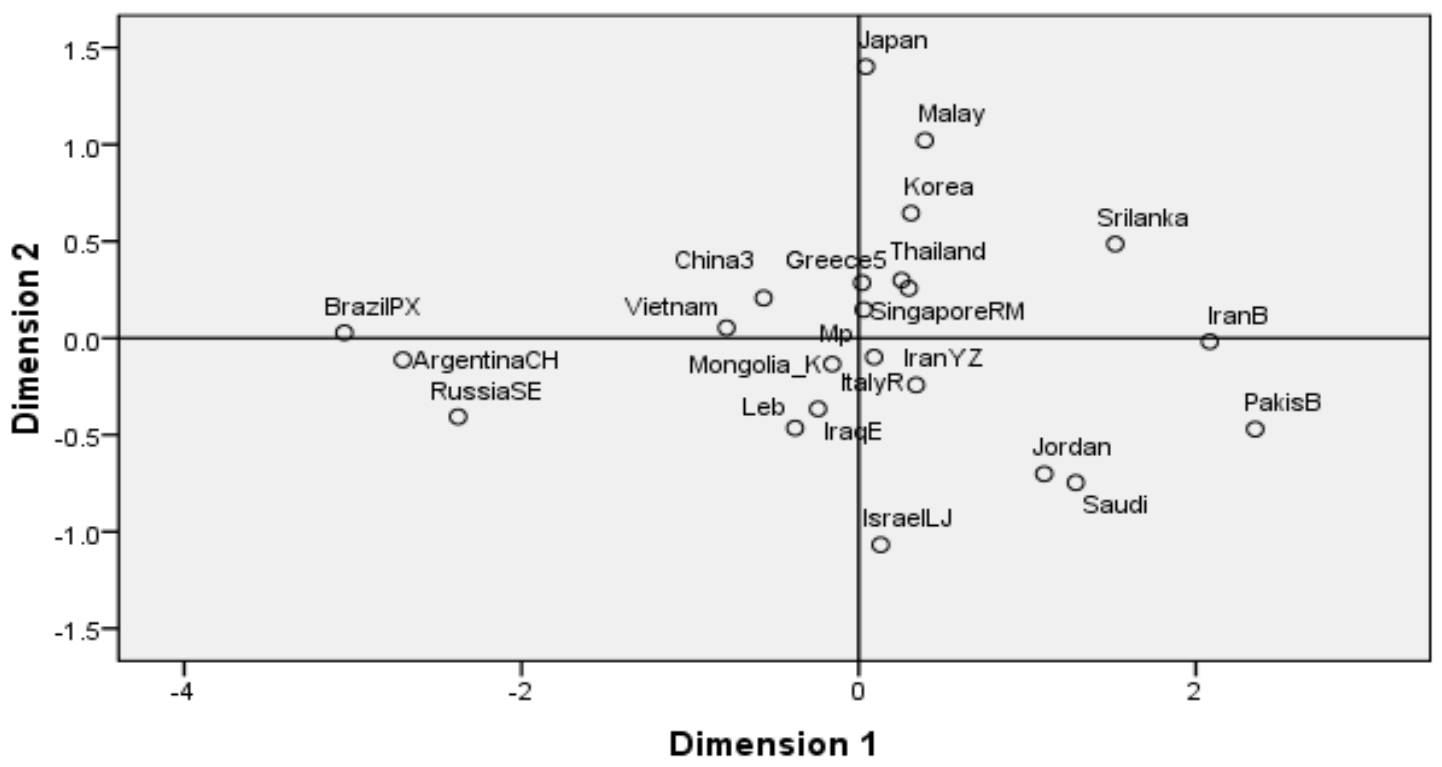

Fig. 4 MDS plot to representation of genetic differences of different world populations 


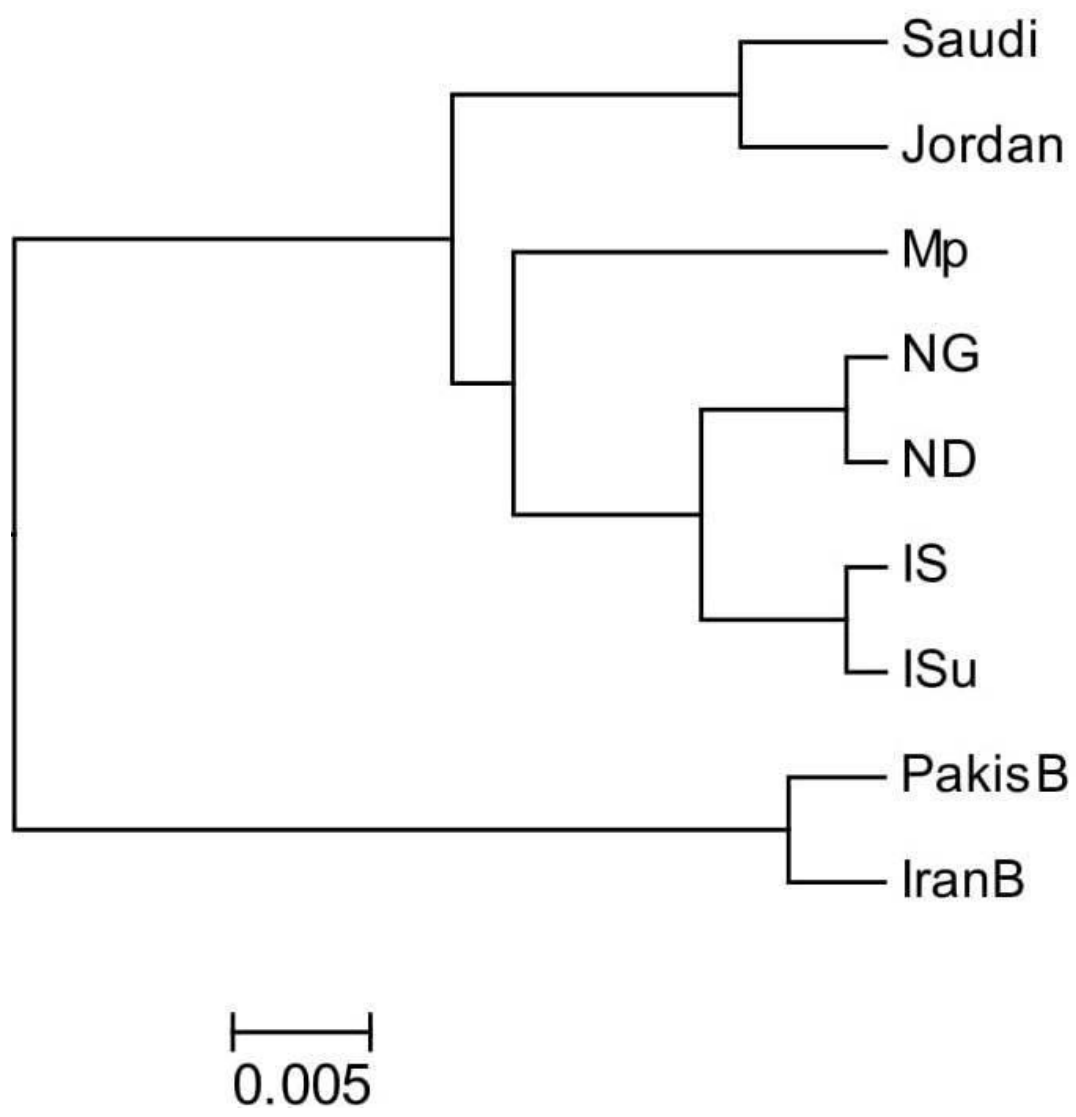

Fig. 5 Neighbor-joining tree showing the genetic relationship among population under the study and Muslims in neighbor country and two other Indian populations based on Nei's genetic distances.

\section{Conclusion}

The results of this study demonstrate close relation between Muslims in South Karnataka and other Indian sub-populations although well separation with other Muslim population in North India has been illustrated unlike primary assumption. It can be concluded that Muslim population of present study most probably have been admixed genetically with neighbor populations in Southern region of India. Preferably, the results of present study might be fully explored and deepened when all HLA loci or at least all loci of each classes to be analyzed with high resolution genotyping.

Conflicts of Interest: The authors declare no conflict of interest. 


\section{References}

Agrawal S., Srivastava S.K., Borkar M., Chaudhuri T.K. 2008. Genetic affinities of north and northeastern populations of India: inference from HLA-based study. Tissue Antigens 72(2): 120130. DOI: https://doi.org/10.1111/j.1399-0039.2008.01083.x

Amar A., Kwon O.J., Motro U., Witt C.S., Bonne-Tamir B., Gabison R, Brautbar C. 1999. Molecular analysis of HLA class II polymorphisms among different ethnic groups in Israel. Human immunology 60(8):.723-730.

DOI: https://doi.org/10.1016/S0198-8859(99)00043-9

Begovich A.B., Moonsamy P.V., Mack S.J., Barcellos L.F., Steiner L.L., Grams S., Suraj-Baker V., Hollenbach J., Trachtenberg E., Louie L, Zimmerman P. 2001. Genetic variability and linkage disequilibrium within the HLA-DP region: analysis of 15 different populations. Tissue antigens 57(5): 424-439.

DOI: https://doi.org/10.1034/j.1399-0039.2001.057005424.X

Borg I. and Groenen P. 2003. Modern multidimensional scaling: Theory and applications. Journal of Educational Measurement 40(3): .277-280.

DOI: https://doi.org/10.1111/j.1745-3984.2003.tb01108.x

Cerna M., Falco M., Friedman H., Raimondi E., Maccagno A., Fernandez-Viña M., Stastny P. 1993. Differences in HLA class II alleles of isolated South American Indian populations from Brazil and Argentina. Human immunology 37(4): .213-220.

DOI: https://doi.org/10.1016/0198-8859(93)90504-T

Chandanayingyong D. 2002. Presented at 7th Asia-Oceania Histocompatibility Workshop and Conference. Data obtained from: http://allelefrequencies.net/pop6001c.asp?pop_name=Thailand

Excoffier L. and Lischer H.E. 2010. Arlequin suite ver 3.5: a new series of programs to perform population genetics analyses under Linux and Windows. Molecular ecology resources 10(3): 564-567. DOI: https://doi.org/10.1111/j.1755-0998.2010.02847.x

Farjadian S., Naruse T., Kawata H., Ghaderi A., Bahram S., Inoko H. 2004. Molecular analysis of HLA allele frequencies and haplotypes in Baloch of Iran compared with related populations of Pakistan. Tissue antigens 64(5): 581-587.

DOI: https://doi.org/10.1111/j.1399-0039.2004.00302.x 
Gjertson D.W. and Terasaki P.I. 1998. HLA 1998. American Society for Histocompatibility and Immunogenetics. Human Immunology short population report. Data obtained from: http://allelefrequencies.net/pop6001c.asp?pop name=India\%20Lucknow

Hoa B.K., Hang N.T.L., Kashiwase K., Ohashi J., Lien L.T., Horie T., Shojima J., Hijikata M., Sakurada S., Satake M., Tokunaga K. 2008. HLA-A,-B,-C,-DRB1 and-DQB1 alleles and haplotypes in the Kinh population in Vietnam. Tissue Antigens 71(2): 127-134.

DOI: https://doi.org/10.1111/j.1399-0039.2007.00982.x

Kohaar I., Hussain S., Thakur N., Tiwari P., Nasare V., Batra S., Singh V., Bhambani S., Das B.C., Sarkar D.P., Bharadwaj M. 2009. Association between human leukocyte antigen class II alleles and human papillomavirus-mediated cervical cancer in Indian women. Human immunology 70(4): 222-229. DOI: https://doi.org/10.1016/j.humimm.2009.01.003

Kokaraki G., Daniilidis M., Yiangou M., Arsenakis M., Karyotis N., Tsilipakou M., Fleva A., Gerofotis A., Karadani N., Yovos J.G. 2009. Major histocompatibility complex class II (DRB1*, DQA1*, and DQB1*) and DRB1* 04 subtypes' associations of Hashimoto's thyroiditis in a Greek population. Tissue Antigens 73(3): 199-205.

DOI: https://doi.org/10.1111/j.1399-0039.2008.01182.x

Krylov M., Erdesz S., Alexeeva L., Benevolenskaya L., Arnett F.C., Reveille J.D. 1995. HLA class II and HLA-B27 oligotyping in two Siberian native population groups. Tissue Antigens 46(5): 382-386. DOI: https://doi.org/10.1111/j.1399-0039.1995.tb03130.x

Latter B.D.H. 1972. Selection in finite populations with multiple alleles. III. Genetic divergence with centripetal selection and mutation. Genetics 70(3): 475-490.

DOI: https://www.ncbi.nlm.nih.gov/pubmed/5024717

Machulla H.K., Batnasan D., Steinborn F., Uyar F.A., Saruhan-Direskeneli G., Oguz F.S., Carin M.N., Dorak M.T. 2003. Genetic affinities among Mongol ethnic groups and their relationship to Turks. Tissue Antigens 61(4): 292-299.

DOI: https://doi.org/10.1034/j.1399-0039.2003.00043.x

Malavige G.N., Rostron T., Seneviratne S.L., Fernando S., Sivayogan S., Wijewickrama A., Ogg G.S. 2007. HLA analysis of Sri Lankan Sinhalese predicts North Indian origin. International journal of immunogenetics 34(5): 313-315.

DOI: https://doi.org/10.1111/j.1744-313X.2007.00698.X 
Mohyuddin A., Ayub Q., Khaliq S., Mansoor A., Mazhar K., Rehman S., Mehdi S.Q. 2002. HLA polymorphism in six ethnic groups from Pakistan. Tissue antigens 59(6): 492-501.

DOI: https://doi.org/10.1034/j.1399-0039.2002.590606.x

Piancatelli D., Canossi A., Aureli A., Oumhani K., Del Beato T., Di Rocco M., Liberatore G., Tessitore A., Witter K., El Aouad R., Adorno D. 2004. Human leukocyte antigen-A,-B, and-Cw polymorphism in a Berber population from North Morocco using sequence-based typing. Tissue antigens 63(2): 158-172.

DOI: https://doi.org/10.1111/j.1399-0039.2004.00161.x

Saito S., Ota S., Yamada E., Inoko H., Ota M. 2000. Allele frequencies and haplotypic associations defined by allelic DNA typing at HLA class I and class II loci in the Japanese population. Tissue antigens 56(6): 522-529.

DOI: https://doi.org/10.1034/j.1399-0039.2000.560606.x

Samaha H., Rahal E.A., Abou-Jaoude M., Younes M., Dacchache J., Hakime N. 2003. HLA class II allele frequencies in the Lebanese population. Molecular immunology 39(17-18): 10791081. DOI: https://doi.org/10.1016/S0161-5890(03)00073-7

Sanchez-Mazas A. 2001. African diversity from the HLA point of view: influence of genetic drift, geography, linguistics, and natural selection. Human immunology 62(9): 937-948.

DOI: https://doi.org/10.1016/S0198-8859(01)00293-2

Sanchez-Mazas A. 2007. HLA genetic differentiation of the 13th IHWC population data relative to worldwide linguistic families. In Immunobiology of the MHC: Proceedings of the 13th International Histocompatibility Workshop and Conference (Vol. 1, p. 758). IHWG Press Seattle. DOI: https://archive-ouverte.unige.ch/unige:14875

Sánchez-Velasco P., Karadsheh N.S., García-Martín A., de Alegría C.R., Leyva-Cobián F. 2001. Molecular analysis of HLA allelic frequencies and haplotypes in Jordanians and comparison with other related populations. Human immunology 62(9): 901-909.

DOI: https://doi.org/10.1016/S0198-8859(01)00289-0

Seshasubramanian V., Manisekar N.K., Sathishkannan A.D., Naganathan C., Narayan S. 2018. Next Generation Sequencing in HLA Haplotype distribution among Telugu Speaking Population from Andhra Pradesh, India. Human immunology.

DOI: https://doi.org/10.1016/j.humimm.2018.05.005 
Spínola H., Couto A.R., Peixoto M.J., Anagnostou P., Destro-Bisol G., Spedini G., Lopéz-Larrea C., Bruges-Armas J. 2011. HLA Class-I Diversity in Cameroon: Evidence for a North-South Structure of Genetic Variation and Relationships with African Populations. Annals of human genetics 75(6): 665-677.

DOI: https://doi.org/10.1111/j.1469-1809.2011.00672.x

Takezaki N., Nei M., Tamura K. 2009. POPTREE2: Software for constructing population trees from allele frequency data and computing other population statistics with Windows interface. Molecular biology and evolution 27(4): 747-752.

DOI: https://doi.org/10.1093/molbev/msp312

Tatusova T.A. and Madden T.L. 1999. Erratum to "BLAST 2 Sequences, a new tool for comparing protein and nucleotide sequences"[FEMS Microbiol. 174 (1999) 247-250] 1. FEMS Microbiology Letters 177(1): 187-188.

DOI: https://doi.org/10.1111/j.1574-6968.1999.tb13730.x

Testi M. and Mariani M. 1998. Caucasian Italian normal. Am Soc Histocompat Immunogenet Lenexa, KS, USA, 165.

Zhao Y.P., Yang J.Q., Ge Y., Fan L.A., Loiseau P., Colombani J. 1993. HLA-DR and DQB1 genotyping in a chonese population. International Journal of Immunogenetics 20(4): 293-297. DOI: https://doi.org/10.1111/j.1744-313X.1993.tb00146.x

González-Galarza F.F., Takeshita L.Y., Santos E.J., Kempson F., Maia M.H.T., Silva A.L.S.D., Silva A.L.T.E., Ghattaoraya G.S., Alfirevic A., Jones A.R., Middleton D. 2014. Allele frequency net 2015 update: new features for HLA epitopes, KIR and disease and HLA adverse drug reaction associations. Nucleic acids research 43(D1): D784-D788.

DOI: https://doi.org/10.1093/nar/gku1166

Robinson J., Halliwell J.A., Hayhurst J.D., Flicek P., Parham P., Marsh S.G. 2014. The IPD and IMGT/HLA database: allele variant databases. Nucleic acids research 43(D1): D423-D431. DOI: https://doi.org/10.1093/nar/gku1161

Marsh S.G., Albert E.D., Bodmer W.F., Bontrop R.E., Dupont B., Erlich H.A., Fernández-Viña M., Geraghty D.E., Holdsworth R., Hurley C.K., Lau M. 2010. Nomenclature for factors of the HLA system, 2010. Tissue antigens 75(4): 291-455.

DOI: https://doi.org/10.1111/j.1399-0039.2010.01466.x 
Sanchez-Mazas A., Fernandez-Viña M., Middleton D., Hollenbach J.A., Buhler S., Di D., Rajalingam R., Dugoujon J.M., Mack S.J. and Thorsby E., 2011. Immunogenetics as a tool in anthropological studies. Immunology 133(2): 143-164.

DOI: https://doi.org/10.1111/j.1365-2567.2011.03438.x

Eaaswarkhanth M., Haque I., Ravesh Z., Romero I.G., Meganathan P.R., Dubey B., Khan F.A., Chaubey G., Kivisild T., Tyler-Smith C., Singh L. 2010. Traces of sub-Saharan and Middle Eastern lineages in Indian Muslim populations. European Journal of Human Genetics 18(3): 354. DOI: https://doi.org/10.1038/ejhg.2009.168

Khan F., Phadke S., Nityanand S., Talwar S., Agrawal S. 2004. Use of ApoB3' hyper variable region in studying mixed chimerism and maternal contamination in North Indian populations. Journal of clinical forensic medicine 11(4): 183-188.

DOI: https://doi.org/10.1016/j.jcfm.2003.12.007

To cite this article:

Koohyar Mohsenpour, Adimoolam Chandrasekar. 2019. Genetic affinity of Muslim population in South India based on HLA-DQB1 and relationship with other Indian Populations. International Journal of Modern Anthropology. 2 (12): 97-113 DOI: http://dx.doi.org/10.4314/ijma.v2i12.4

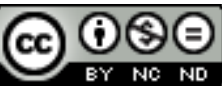

This article, as all articles published in this journal, is under The Creative Commons Attribution: Attribution-NonCommercial-NoDerivatives 4.0 International (CC BY-NC-ND 4.0). https://creativecommons.org/licenses/by-nc-nd/4.0/ 